\title{
Influence of artificial grassland restoration on soil carbon pool in an arid mining land
}

\author{
Yan $\mathrm{Mu}^{1,2}$, Yu Liu ${ }^{2}$, Fu-Ping Tian ${ }^{3}$, Xiao-Feng Chang ${ }^{2}$, Gao-Lin $\mathrm{Wu}^{1,2 *}$ \\ ${ }^{1}$ College of Landscape Architectural and Arts, Northwest A \& F University, Yangling, Shaanxi 712100, China. ${ }^{2}$ State Key \\ Laboratory of Soil Erosion and Dryland Farming on the Loess Plateau, Institute of Soil and Water Conservation, Chinese \\ Academy of Sciences and Ministry of Water Resources, Yangling, Shaanxi 712100, China. ${ }^{3}$ The Lanzhou Scientific Observation \\ and Experiment Field Station of Ministry of Agriculture for Ecological System in the Loess Plateau Area, Lanzhou Institute of \\ Animal and Veterinary Pharmaceutics Sciences, Chinese Academy of Agricultural Sciences, Lanzhou, Gansu 730050 China. \\ *Corresponding author: gaolinwu@gmail.com
}

\begin{abstract}
Successful reclamation of degraded mine land can contribute to recuperate the vegetation and soil carbon sequestration. In this study, soil carbon pool was assessed in a mining land after short-term reclamation. We measured above- and belowground biomass and soil carbon storage of artificial grassland (Astragalus adsurgens and Medicago sativa), which was established in the reclamation of mining land. The results showed that artificial grassland establishment significantly increased above- and belowground biomass after four-year restoration. Artificial grassland establishment increased soil inorganic and organic carbon content and storage. Soil organic and inorganic carbon content showed a positive increasing along the restoration time. Higher SOC and lower soil bulk density and water content all were attributed to the growth of artificial grassland. These results suggest that establishing artificial grassland with legumes is an effective restoration approach for improving soil carbon pool in the reclaimed mine soils.
\end{abstract}

Keywords: Mine land, reclamation, soil carbon, vegetation community

\section{Introduction}

Fossil fuel combustion and other anthropogenic activities, have been continually increasing atmospheric greenhouse gas carbon dioxide $\left(\mathrm{CO}_{2}\right)$ concentrations worldwide, which results in rising global temperatures, hoisting sea levels, and other dangerous effects on the environment (Easterling et al., 2000; Palumbo et al., 2004). Effective managing carbon (C) is the most significant challenge inherent to manage the greenhouse effect (Akala and Lal, 2006). The terrestrial ecosystem plays a major role in moderating the global C cycle, and it is an effective biological scrubber for atmospheric $\mathrm{CO}_{2}$ (Shrestha and Lal, 2006). 
Enhancing $\mathrm{C}$ storage in terrestrial ecosystems is a potential approach to mitigate rising $\mathrm{CO}_{2}$ concentrations (Juwarkar et al., 2010; Palumbo et al., 2004). The biosphere and the pedosphere are the two most important sinks for carbon in the terrestrial ecosystem. The pedosphere, which especially shows potential to sequester $\mathrm{C}$ effectively, plays an important role in the overall management of C (Akala and Lal, 2006; Rosenzweig and Hillel, 1999).

Land degradation is caused by various anthropogenic disturbances including mining, which has caused considerable negative impact on terrestrial ecosystems and led to severe soil degradation in many parts of the world (Akala and Lal, 2000). Soil disturbance caused by mining operations where native vegetation and animal communities have been removed and most of the topsoil lost, altered, and buried. Surface mining eliminates vegetation, permanently changes topography, drastically alters soil geological structure, and disrupts hydrologic regimes (Keskin and Makineci, 2009). About 2.88 Mha of land has been destroyed by mining in China (Bai et al., 1999a), the figure is increasing at an alarming rate of 46,700 ha per year (Bai et al., 1999b). Degraded mine lands are often characterized by acidic $\mathrm{pH}$, poor soil structure, low soil fertility, and limited microbial activity (Ussiri et al., 2006). These soils completely regenerated through normal ecological successional processes, but the processes required decades (Juwarkar et al., 2010).

Despite relatively low levels of key nutrients and poor soil structure, degraded mine land shows considerable C sequestration potential (Akala and Lal, 2001). Reclamation of mine land by soil restoration and reestablishment of vegetative cover could lead to successful $\mathrm{C}$ sequestration, such as accelerating the natural processes, mitigating negative environmental consequences associated with mining (Akala and Lal, 2000; Yang et al., 2015). Retaining SOC by creating a conducive environment for vegetation regeneration can sequester $\mathrm{C}$ and reduce greenhouse effect ultimately. SOC level is an indicator of soil maturity, as well as potential reservoirs for C storage (Rosenzweig and Hillel, 1999; Juwarkar et al., 2010). Depleted SOC pools in reclaimed mine soil ecosystems could be identified according to comparing the SOC level to undisturbed or otherwise similar soils. SOC could be restored through appropriate land use and adoption of scientifically recommended management practices (Guo et al., 2015; Merino et al., 2015; Wu et al., 2016a; 2016b). In order to accurately estimate $\mathrm{C}$ storage in soil, both organic and inorganic pools must be considered (Liu et al., 2016). The SIC pool is an important part of the total soil C pool (Hirmas et al., 2010). Soil inorganic carbon (SIC) sequestration is the immobilization of $\mathrm{C}$ in the form of pedogenic carbonates, and leaching of carbonates and bicarbonates into the ground water (Akala and Lal, 2006; Tan et al., 2014). The necessary magnitude of SIC exchange in the atmosphere is another very lengthy process, but the formation of secondary carbonate in soil is an effective $\mathrm{C}$ sequestration mechanism (Mi et al., 2008). Accumulation of SOC and SIC is a fundamental component of the successful restoration of degraded mine land.

Mining-related SOC depletion trends can be reversed by effective reclamation of mine lands. Reconstructing mine land soil quality requires successfully employing vegetation to improve physical, chemical, and biological soil condition (Bendfeldt et al., 2001). In the present study, abandoned mine land was reclaimed by establishing artificial grasslands to improve the soil organic and inorganic carbon pool. The primary objectives of this paper were to (1) evaluate SOC and SIC stocks as short-term restoration in abandoned mine land; and (2) explore their relation with physical and chemical soil properties in restorated mine land. 


\section{Materials and Methods}

\subsection{Study area}

The experimental area $\left(39^{\circ} 41^{\prime} \mathrm{N}, 110^{\circ} 16^{\prime} \mathrm{E}\right.$, altitude, $1413 \mathrm{~m}$ a.s. 1.) is located at Jungar Banner, Ordos City, China. The study area is a well-known coal mine resource and its land surface was mined extensively and subsequently reclaimed. It belongs to a semi-arid continental temperate monsoon climate. According to the data available for the period 2001-2013 at the study site provided by the
National Meteorological Information Center of China, the mean annual air temperature is $7.33^{\circ} \mathrm{C}$. The annual precipitation is $384.75 \mathrm{~mm}$, mainly occurring between July and September (Figure 1). The mean annual evaporation capacity is 1824.7 $2896.1 \mathrm{~mm}$, which is approximately three times as much as the mean annual precipitation. Vegetation is dominated by Caragana intermedia Hippophae rhamnoides, Aremsia gmelinii, and Bothriochloa ischaemum. The dominate soil types are aeolian sandy soil and loessial soil, which is infertile and extremely susceptible to erosion.

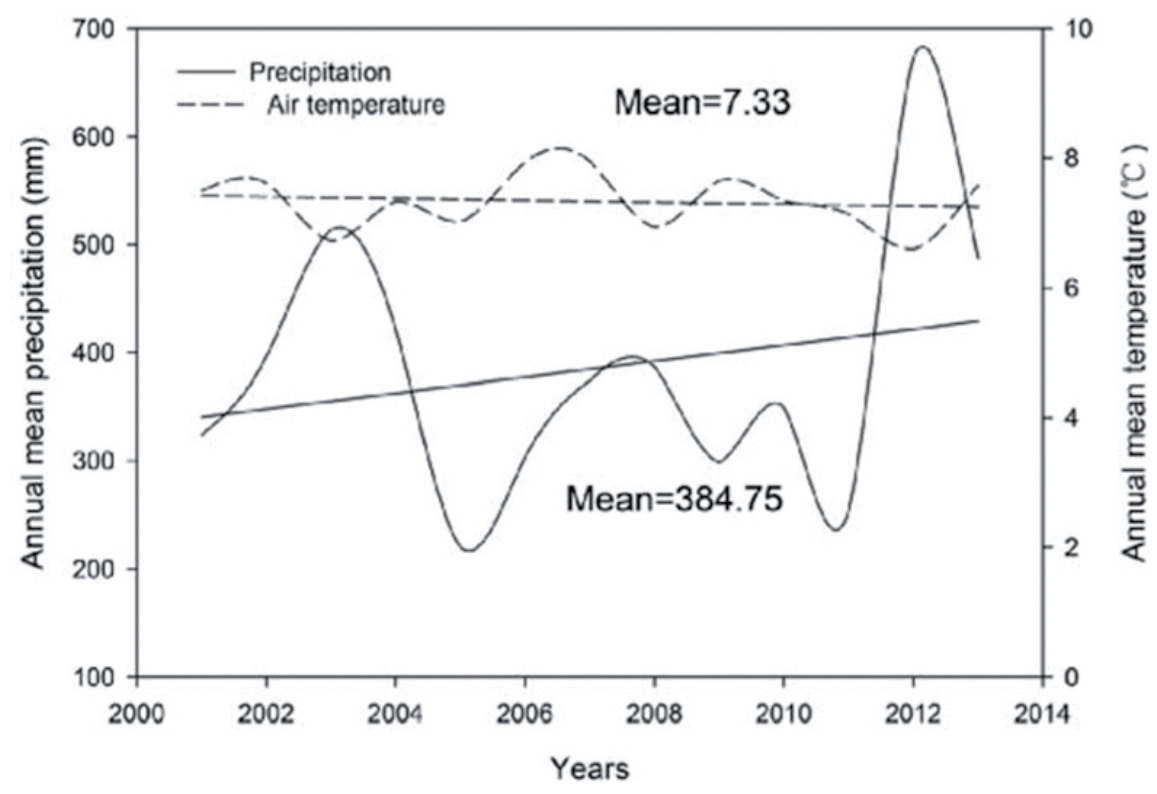

Figure 1. Annual mean temperature and annual mean precipitation at study site 2001-2013. Note: straight lines in the figure represent the dynamic fitting curve for annual mean temperature and annual mean precipitation changes with time.

\subsection{Experimental design}

This study compared four different grasslands: 1-year, 2-year, 3-year and 4-year-established artificial grasslands, with Astragalus adsurgens and Medi- cago sativa on the reclamation land areas and one newly reclaimed land as a control (Figure 2). Each treatment block was about 1 ha and it was comprised by five sampling plots $(30 \mathrm{~m} \times 30 \mathrm{~m})$ with random arrangement. Blocks were separated by iron fences. 
In each of sampling plots of the four grassland types, we established five diagonal sampling quadrants (1.0 $\mathrm{m} \times 1.0 \mathrm{~m})$ to investigate and sample. The growing season is from April to September in study area. The artificial grasslands in our study are excluded from grazing all year.

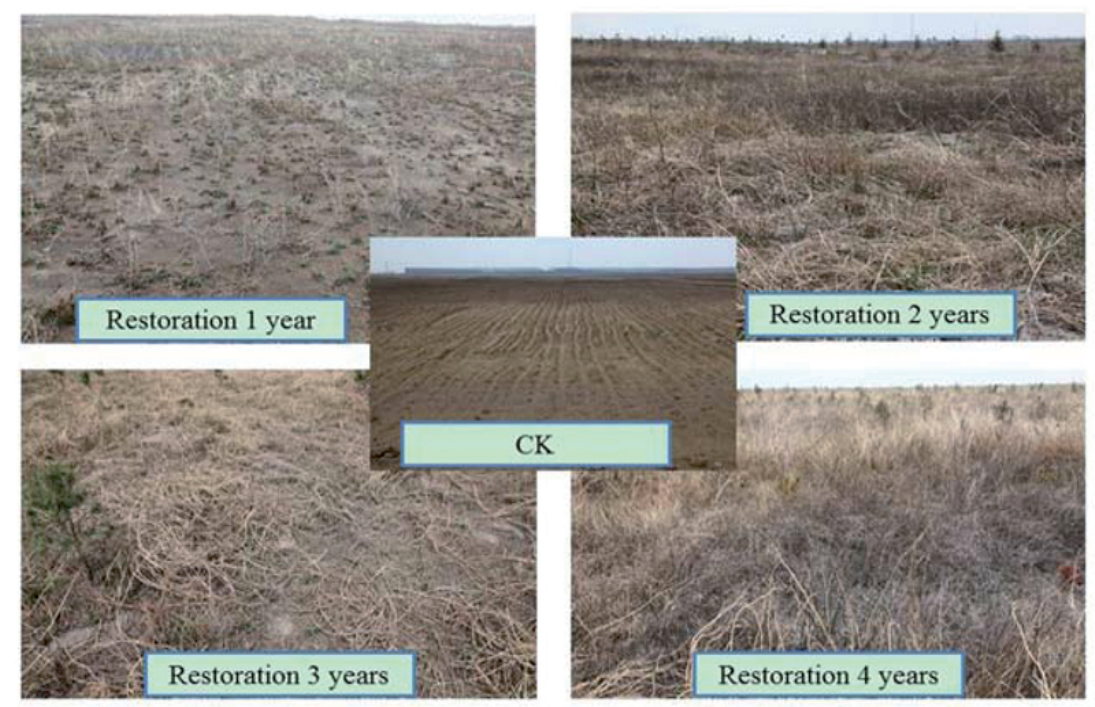

Figure 2. Four restored grasslands in this study (1-year grassland restoration, R1; 2-year grassland restoration, R2; 3-year grassland restoration, R3; 4-year grassland restoration, R4).

\subsection{Soil sampling and determination}

Soil samples were taken at five points in each quadrant. Soil sampling was performed with a soil drilling sampler ( $9 \mathrm{~cm}$ inner diameter) in three soil layers, $0-10,10-20$, and $20-30 \mathrm{~cm}$. The same layers were then mixed together to make one sample. All samples were sieved through a $2 \mathrm{~mm}$ screen to remove roots and other debris. Soil samples were air-dried and then passed through a $0.14 \mathrm{~mm}$ sieve. Soil $\mathrm{pH}$ was determined using a soil-water ratio of $1: 5$, and soil water content before air drying was obtained by the oven-drying method. The soil bulk density $\left(\mathrm{g} \mathrm{cm}^{-3}\right)$ of the different soil layers was measured using the soil cores (volume, $100 \mathrm{~cm}^{3}$ ) with the volumetric ring method (Wu et al., 2010). Soil organic carbon was assayed by dichromate oxidation (Kalembasa and Jenkinson, 1973). Soil inorganic carbon was measured using the calcimeter method, based on the reaction of SIC with $\mathrm{HCl}$ to $\mathrm{CO}_{2}$ (Vuong et al., 2013). Each analysis was completed in three replicates. The following equation was used to calculate soil organic carbon storage (SOS) (Deng et al., 2013):

$\mathrm{SOS}=\mathrm{BD} \times \mathrm{SOC} \times \mathrm{D} / 10$

in which $\mathrm{SOS}$ is soil organic carbon storage $(\mathrm{Mg}$ $\left.\mathrm{ha}^{-1}\right)$, BD is soil bulk density $\left(\mathrm{g} \mathrm{m}^{-3}\right)$, SOC is soil organic carbon concentration $\left(\mathrm{g} \mathrm{kg}^{-1}\right)$, and $\mathrm{D}$ is soil thickness (cm). 


\subsection{Plant sampling}

In each quadrant, aboveground plant parts were cut, collected, and put into envelopes and tagged in early September. To measure belowground biomass, soil sampling was done three times in three soil layers, $0-10,10-20$, and $20-30 \mathrm{~cm}$ at a depth of $0-30 \mathrm{~cm}$ in each quadrant using a $9 \mathrm{~cm}$-diameter root auger. The majority of the roots were found in the soil samples as-obtained and isolated using a $0.5 \mathrm{~mm}$ sieve. This process likely failed to distinguish all dead root tissue, so thus is referred to as standing root mass measurement. The root tissue and aboveground plant were dried at $80^{\circ} \mathrm{C}$ for $48 \mathrm{~h}$ and weighed to determine the dry biomass.

\subsection{Statistical analyses}

All data were expressed as mean \pm standard error (SE). One-way ANOVA analyses were conducted to identify the effects of establishment time of artificial grassland on aboveground/belowground biomass, SIS, SOS, SIC, and SOC. Post hoc comparisons were made using Tukey's honest significant difference (HSD). Significant differences were evaluated at the 0.05 level. Pearson Correlation analyses were used to test the relationships between soil and plant factors. Regression parameters and figures were calculated by Sigmaplot Version 12.5 (Systat Software Inc., San Jose, CA, USA) and statistical tests were carried out using SPSS Version 17.0 (SPSS, Chicago, IL, USA).

\section{Results}

\subsection{Plant community response and soil properties}

Artificial grassland establishment significantly increased aboveground biomass after three years of restoration $(p<0.05)$ from $\mathrm{R} 1 \quad\left(64.14 \pm 11.47 \mathrm{~g} \mathrm{~m}^{-2}\right)$

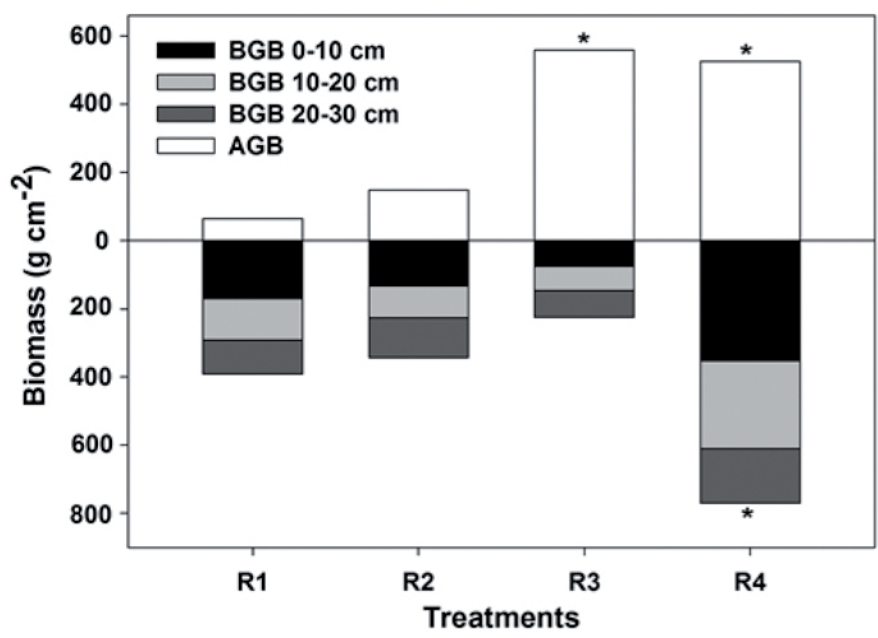

Figure 3. Changes in aboveground biomass (AGB) and belowground biomass (BGB) within three soil depths for 1-, 2-, 3-, and 4- year (R1, R2, R3, R4) artificial grasslands. Significant differences in AGB and BGB between different restoration times are indicated by asterisks at $p<0.05$. 
and also significantly increased the belowground biomass after four years of restoration $(p<0.05$; Figure 3) from R3 $\left(225.88 \pm 8.92 \mathrm{~g} \mathrm{~m}^{-2}\right)$ to $\mathrm{R} 4(770.31$ $\pm 172.37 \mathrm{~g} \mathrm{~m}^{-2}$ ) at $0-30 \mathrm{~cm}$ depth. As for soil properties among R1, R2, R3, and R4 grasslands, artificial grassland establishment decreased soil bulk density (Figure 4a) and soil water content (Figure 4b), but there were no significant effects caused by number of restoration years or soil depths on soil bulk density or soil water content.

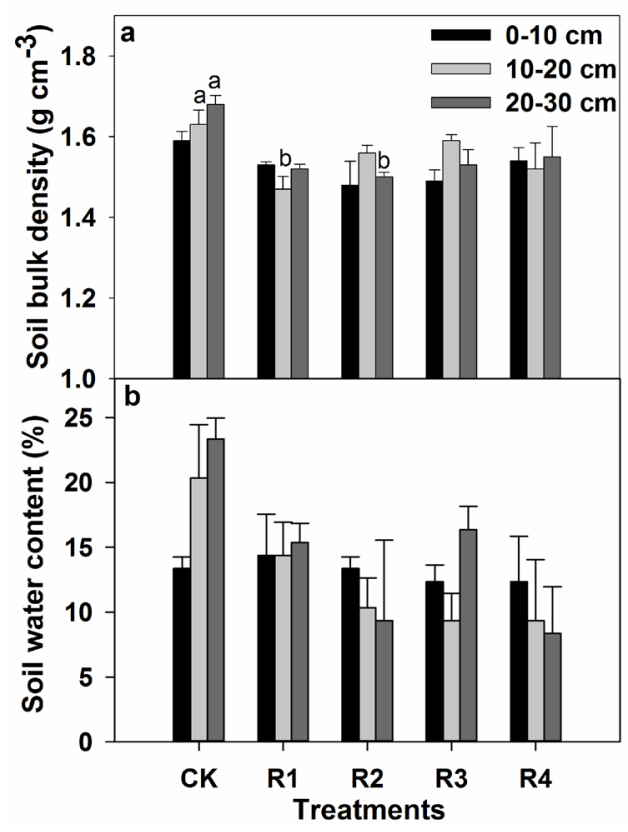

Figure 4. Changes in soil water content (b) and soil bulk density (a) within three soil depths for newly reclaimed land (CK) and 1-, 2-, 3-, and 4-year (R1, $\mathrm{R} 2, \mathrm{R} 3, \mathrm{R} 4)$ artificial grasslands. The different letters represent the significant differences at $p<0.05$.

\subsection{Soil carbon content response and storage}

There was a positive effect of soil inorganic and organic carbon content on artificial grassland. Establishing artificial grassland increased both soil inorganic and organic carbon content (Figure 5). R2 showed the highest inorganic carbon content (Figure 5a) and R1 showed the highest organic carbon content (Figure $5 b)$ in the study period. Soil organic carbon content increased from $0.58 \pm 0.07 \mathrm{~g} \mathrm{~kg}^{-1}$ to $0.92 \pm 0.06 \mathrm{~g} \mathrm{~kg}^{-1}$, and soil inorganic carbon content increased from 3.55 $\pm 0.14 \mathrm{~g} \mathrm{~kg}^{-1}$ to $7.78 \pm 0.23 \mathrm{~g} \mathrm{~kg}^{-1}$ at the $0-30 \mathrm{~cm}$ depth over 4 years. Restoration time had no significant impact on soil inorganic/organic carbon content.

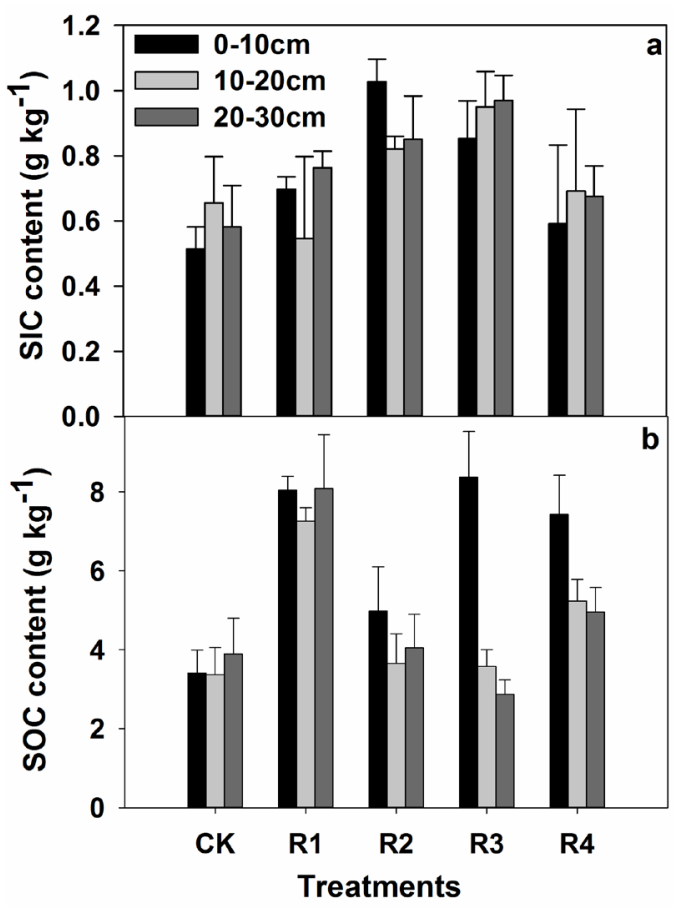

Figure 5. Changes in soil inorganic carbon (SIC) content (a) and soil organic carbon (SOC) content (b) within three soil depths for newly reclaimed land (CK) and 1-, 2-, 3-, and 4-year (R1, R2, R3, R4) artificial grasslands. 
Similar trends were observed for soil inorganic and organic carbon storage; establishing artificial grassland increased soil inorganic and organic carbon storage. The soil inorganic carbon storage in R2 was higher than CK, R1, R3, and R4 grasslands (Figure 6a). Soil organic carbon storage in R1 was found the higher than the other grasslands (Figure 6b). Soil organic carbon storage in the artificial grassland increased from $17.58 \pm 3.14 \mathrm{Mg} \mathrm{ha}^{-1}$ to $35.27 \pm 14.62$ $\mathrm{Mg} \mathrm{ha}^{-1}$, and soil inorganic carbon storage increased from $2.85 \pm 0.52 \mathrm{Mg} \mathrm{ha}^{-1}$ to $4.26 \pm 0.18 \mathrm{Mg} \mathrm{ha}^{-1}$ at $0-30 \mathrm{~cm}$ depth.

Table 1. Pearson correlation coefficients between bulk density (BD), soil water content (SWC), coverage, height, belowground biomass (BGB), aboveground biomass (AGB), soil organic carbon content (SOC), and soil inorganic carbon content (SIC).

\begin{tabular}{lrrrrrrrr}
\hline & Coverage & Height & AGB & BGB & BD & SWC & SOC & SIC \\
\hline Years & $0.883^{* *}$ & -0.306 & $0.734^{* *}$ & 0.418 & -0.355 & $-0.687^{* *}$ & 0.074 & 0.125 \\
Coverage & & $-0.492^{*}$ & $0.679^{* *}$ & 0.249 & 0.107 & -0.406 & -0.190 & 0.104 \\
Height & & & -0.169 & 0.218 & -0.100 & 0.268 & 0.208 & -0.074 \\
AGB & & & & 0.026 & 0.112 & -0.035 & -0.133 & 0.090 \\
BGB & & & & & 0.245 & -0.097 & -0.004 & -0.297 \\
BD & & & & & & $0.605^{*}$ & -0.144 & -0.168 \\
SWC & & & & & & & 0.165 & -0.092 \\
SOC & & & & & & & & -0.351 \\
\hline
\end{tabular}

Note: $* \mathrm{P}<0.05 ; * * \mathrm{P}<0.01$

\subsection{Relationship between community and soil properties}

Correlation analyses showed that the restoration time significantly positively related to community coverage $(\mathrm{R}=0.883, p<0.01)$ and aboveground biomass $(\mathrm{R}=0.734, p<0.01)$, and significantly negatively related to soil water content $(\mathrm{R}=-0.6874, p<0.01$; Table 1$)$. Community coverage significantly negatively related to plant height $(\mathrm{R}=-0.492, p<0.05)$ and positively related to aboveground biomass $(\mathrm{R}=0.679, p<0.01)$. Soil water content and bulk density showed a significant positive correlation $(\mathrm{R}=0.605, p<0.05$; Table 1$)$. Soil organic and inorganic carbon content showed a positive correlation with short-term restoration, but the relation was not significant $(p>0.05$, Table 1$)$. 


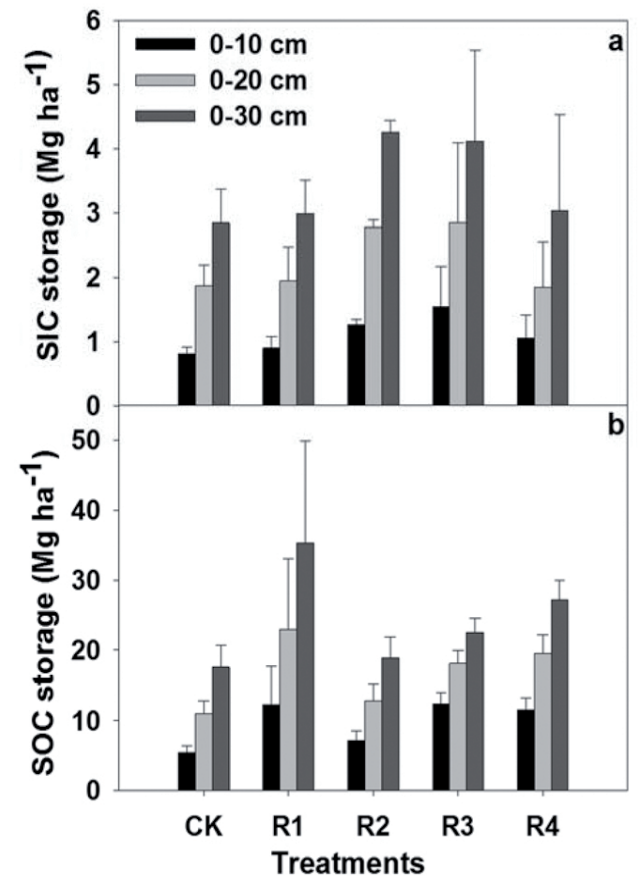

Figure 6. Changes in soil inorganic carbon (SIC) storage (a) and soil organic carbon (SOC) storage (b) within three soil depths for newly reclaimed land (CK) and 1-, 2-, 3-, and 4-year (R1, R2, R3, R4) artificial grasslands.

\section{Discussion}

Rebuilding Astragalus adsurgens and Medicago sativa grasslands artificially is vital for successful restoration of vegetation productivity at abandoned mine lands. 3-year grassland restoration showed significantly more aboveground biomass than 1 and 2-year grassland restoration. There were distinct reductions in soil bulk density and soil water content after mine land reclamation. This result is consistent with the results found by Zhao et al. (2013), who observed that reclamation significantly decreased the bulk density of mined soil. Alfalfa (Medicago sativa) has been proven as one of the productive forage crops, and also is one of the effective artificial vegetation materials to conserve soil (Zhao et al., 2004). Alfalfa depleted so much soil water through evapotranspiration and resulted in a distinctive and persistent dry layer (with soil water content close to wilting points) at its root depth (Al-Rumikhani, 2002; Wang et al., 2010).

The accumulation of SOC in mining soils has been previously recognized as the key factor in activation of soil biological processes and nutrient maintenance (Lorenz and Lal, 2007). SOC is typically deficient in mine soil, which limits long-term vegetation establishment for restoration of degraded grassland.Factors that affected $\mathrm{C}$ storage and protection in reclaimed mine soil include microbial activity, nutrient availability, soil aggregation, $\mathrm{C}$ build-up, and soil profile. Establishing grassland in mine land can increased soil inorganic and organic carbon storages. This phenomenon is possibly dependent on aboveground biomass growth and input, and increased capacity of the mine lands to sequester $\mathrm{C}$. Legumes derived $\mathrm{N}$ is qualitatively important for building up soil organic matter and carbon storage (Wu et al., 2016a).

Successfully utilizing vegetation for $\mathrm{C}$ sequestration may require extensive and long-term effort. During initial stages of reclamation, legumes show a great deal of potential in sequestrated carbon. Legumes added $\mathrm{N}$ to the soil, which in turn enhances soil $\mathrm{N}$ supply rates and sustains plant growth in a positive feedback loop (Wu et al., 2016a). The increasing biomass and litter can provide more organic matter inputs, which increased the relative decomposition rates of SOC. The plant needed to deplete some SOC to sustain growth as restoration time increase, but parts of the plant tissues that fell and then created soil organic matter input to help maintain a high level of SOC effectively in the top soil $(0-10 \mathrm{~cm})$. The accumulation of organic matter was previously 
recognized as the primary mechanism in the activation of soil biological processes (Sourkova et al., 2005; Frouz et al., 2007). The development of these active microbial populations had a direct impact on the activation of vital organic compound transformation processes, and release of inorganic forms of nitrogen and phosphorus that are directly available to growing plants (Heras, 2009).

SIC exists largely in the form of pedogenic calcite, which is present in semi-arid and arid regions in the form of calcareous, calcic, and petrocalcic horizons (Hirmas et al., 2010).Thus, SIC sequestration is likely The plant needed to deplete some SOC to sustain growth as restoration time increase, but parts of the plant tissues that fell and then created soil organic matter input to help maintain a high level of SOC effectively in the top soil $(0-10 \mathrm{~cm})$. The accumulation the most significant pathway of $\mathrm{C}$ sequestration in arid and semi-arid regions. Our study showed that reclamation of mine lands increases SIC content and storage, the highest values of which are $1.03 \pm 0.07 \mathrm{~g}$ $\mathrm{kg}^{-1}$ and $4.26 \pm 0.18 \mathrm{Mg} \mathrm{ha}^{-1}$, respectively. The decomposition rate of plant residues is about $80-90 \%$ in the arid area of northwest China, and the mineralization rate is 5-10 times that of wet soil (Deng et al., 2013). A large portion of the carbonate parent material, as well as the calcium accumulation, increased the proportion of SIC in the research area. The $\mathrm{CO}_{2}$ partial pressure in the soil and soil moisture increased during the high temperature and rainy summer. As soil water and $\mathrm{CO}_{2}$ partial pressure changed, the $\mathrm{CO}_{2}$ produced by $\mathrm{SOC}$ decomposition converted to carbonate $\mathrm{C}$ by precipitation, formulating a $\mathrm{SOC}-\mathrm{CO}_{2}$-SIC micro carbon cycle system in the soil. So, the ploughing process to establish artificial grassland and then vegetation restoration all could affect the SIC storage, because a change of one of the soil moisture, $\mathrm{pH}, \mathrm{CO}_{2}$ partial pressure, and $\mathrm{Ca}^{2+}$ and $\mathrm{HCO}^{3-}$ concentrations would cause an effect on SIC (Liu et al., 2016).

\section{5 . Conclusions}

Artificial grassland establishment significantly increased above- and belowground biomass after fouryear restoration. Artificial grassland establishment increased soil inorganic and organic carbon content and soil carbon storage. Soil organic/inorganic carbon content showed a positive correlation with short-term restoration, and higher SOC and lower soil bulk density/water content were attributed to artificial grassland growth. The results of this study altogether suggest that establishing artificial grassland by Legumes is an effective restoration approach for improving soil carbon in reclaimed mine soils.

\section{Acknowledgment}

This research was funded by the Project of Natural Science Foundation of China (NSFC41401613, 31372368, 41303062), the "Light of West China" Program of CAS (XAB2015A04), the Action Plan for West Development Project of Chinese Academy of Sciences (KZCX2-XB3-13). The authors thank Dr. Jason Qi for the language revision of this manuscript.

\section{References}

Akala, V.A., Lal, R. 2000. Potential of mine land reclamation for soil organic carbon sequestration in Ohio. Land Degrad. Devel. 11, 289-297.

Akala, V.A., Lal, R. 2001. Soil organic carbon pools and sequestration rates in reclaimed minesoils in Ohio. J. Environ. Qual. 30, 2098-2104.

Akala, V.A., Lal, R. 2006. Soil organic carbon sequestration in reclaimed minesoils. Cheminform 37, 151-165. 
Al-Rumikhani, Y.A. 2002. Effect of crop sequence, soil sample location and depth on soil water holding capacity under center pivot irrigation. Agr. Water Manag. 55, 93-104.

Bai, Z.K., Zhao, J.K., Zhu, Y.M. 1999a. On the ecological rehabilitation of mined areas. J. Nat. Res. 19, 24-28.

Bai, Z.K., Zhao, J.K., Li, J.C.. 1999b. Ecosystem damage in a large opencast coal mine - A case study on pingshuo surface coal mine, China. Acta Ecol. Sin. 19, 870-875.

Bendfeldt, E.S., Burger, J.A., Daniels, W.L. 2001. Quality of amended mine soils after sixteen years. Soil Sci. Soc. Am. J. 65, 1736-1744.

Easterling, D.R., Meehl, G.A., Parmesan, C., Changnon, S.A., Karl, T.R., Mearns, L.O. 2000. Climate extremes: observations, modeling, and impacts. Science 289, 2068-2074.

Deng, L., Wang, K.B., Chen, M.L., Shangguan, Z.P., Sweeney, S. 2013. Soil organic carbon storage capacity positively related to forest succession on the Loess Plateau, China. Catena 110, 1-7.

Frouz, J., Elhottova, D., Pizl, V., Tajovsky, K., Sourkova, M., Picek, T., Maly, S. 2007. The effect of litter quality and soil faunal composition on organic matter dynamics in post-mining soil: A laboratory study. Appl. Soil Ecol. 37, 72-80.

Guo, L.J., Zhang, R.D., Zhang, Z.S., Cao, C.G., Li, C.F. 2015. Effects of different no-tillage modes on soil CO2 fluxes from paddy field in central China. J. Soil Sci. Plant Nutr. 15, 737-750.

Heras, M.D.L. 2009. Development of soil physical structure and biological functionality in mining spoils affected by soil erosion in a MediterraneanContinental environment. Geoderma 49, 249-256.

Hirmas, D.R., Amrhein, C., Graham, R.C. 2010. Spatial and process-based modeling of soil inorganic carbon storage in an arid piedmont. Geoderma 154, 486-494.
Juwarkar, A.A., Mehrotraa, K.L., Nair, R., Wanjari, T., Singh, S.K., Chakrabarti, T. 2010. Carbon sequestration in reclaimed manganese mine land at Gumgaon, India. Environ. Monitor. Assess. 160, 457-464.

Kalembasa, S.J., Jenkinson, D.S. 1973. A comparative study of titrimetric and gravimetric methods for the determination of organic carbon in soil. J. Sci. Food Agri. 24, 1085-1090.

Keskin, T., Makineci, E. 2009. Some soil properties on coal mine spoils reclaimed with black locust (Robinia pceudoacacia L.) and umbrella pine (Pinus pinea L.) in Agacli-Istanbul. Environ. Monitor. Assess. 159, 407-414.

Liu, Y., Dang, Z.Q., Tian, F.P., Wang, D., Wu, G.L. 2016. Soil organic carbon and inorganic carbon accumulation along a 30-year grassland restoration chronosequence in semi-arid regions (China). Land Degred. Develop. DOI: 10.1002/ldr.2632.

Lorenz, K., Lal, R. 2007. Stabilization of organic carbon in chemically separated pools in reclaimed coal mine soils in Ohio. Geoderma. 141, 294-301.

Merino, C., Nannipieri, P., Matus, F. 2015. Soil carbon controlled by plant, microorganism and mineralogy interactions. J. Soil Sci. Plant Nutr. 15, 321-332.

Mi, N., Wan, S.Q., Liu, J.Y., Yu, G.R., Zhang, W.J., Jobbagy, E. 2008. Soil inorganic carbon storage pattern in China. Global Change Biol. 14, 23802387.

Palumbo, A.V., Mccarthy, J.F., Amonette, J.E., Fisher, L.S. Wullschleger, S.D., Daniels, W.L. 2004. Prospects for enhancing carbon sequestration and reclamation of degraded lands with fossil-fuel combustion by-products. Adv. Environ. Res. 8, 425-438.

Rosenzweig, C., Hillel, D. 1999. Soils and global climate change: challenges and opportunities. Soil Sci. 165, 47-56. 
Shrestha, R.K., Lal, R. 2006. Ecosystem carbon budgeting and soil carbon sequestration in reclaimed mine soil. Environ. Inter. 32, 781-796.

Sourkova, M., Frouz, J., Fettweis, U., Bens, O., Huttl, R.F., Santruckova, H. 2005. Soil development and properties of microbial biomass succession in reclaimed post mining sites near Sokolov (Czech Republic) and near Cottbus (Germany). Geoderma. $129,73-80$

Tan, W.F., Zhang, R., Cao, H., Huang, C.Q., Yang, Q.K., Wang, M.K., Koopal, L.K. 2014. Soil inorganic carbon stock under different soil types and land uses on the Loess Plateau region of China. Catena. 121, 22-30

Ussiri, D.A.N., Lal, R., Jacinthe, P.A. 2006. Soil properties and carbon sequestration of afforested pastures in reclaimed minesoils of Ohio. Soil Sci. Soc. Am. J. 70, 1797-1806.

Vuong, T.X., Heitkamp, F., Jungkunst, H.F., Reimer, A., Gerold, G. 2013. Simultaneous measurement of soil organic and inorganic carbon: evaluation of a thermal gradient analysis. J. Soil Sediment $13,1133-1140$

Wang, Y.Q., Shao, M.A., Liu, Z.P. 2010. Large-scale spatial variability of dried soil layers and related factors across the entire Loess Plateau of China. Geoderma. 159, 99-108.
Wu, G.L., Liu, Y., Tian, F.P., Shi, Z.H. 2016a. Legumes functional group promotes soil organic carbon and nitrogen storage by increasing plant diveristy. Land Degred. Develop. DOI: 10.1002/ ldr.2570.

Wu, G.L., Wang, D., Liu, Y., Ding, L.M., Liu, Z.H. 2016b. Warm-season grazing benefits species diversitu consevation and topsoil nutrient sequestration in alpine meadow. Land Degred. Develop. DOI: 10.1002/ldr.2536.

Wu, G.L., Liu, Z.H, Zhang, L., Cheng, J.M., Hu, T.M. 2010. Long-term fencing improved soil properties and soil organic carbon storage in an alpine swamp meadow of western China. Plant Soil 332, 331-337.

Yang, Z., Hao, H.M., Wang, D., Chang, X.F., Zhu, Y.J., Wu, G.L. 2015. Revegetation of artifical grassland improve soil organic and inorganic carbon and water of abandoned mine. J. Soil Sci. Plant Nutr. 15:629-638.

Zhao, C.Y., Feng, Z.D., Chen, G.D. 2004. Soil water balance simulation of alfalfa (Medicago sativa L.) in the semiarid Chinese Loess Plateau. Agr. Water Manage. 69, 101-114.

Zhao, Z.Q., Shahrour, I., Bai, Z.K., Fan, W.X., Feng L.R., Li, H.F. 2013. Soils development in opencast coal mine spoils reclaimed for 1-13 years in the West-Northern Loess Plateau of China. Eur. J. Soil Biol. 55, 40-46. 